\title{
Post-weaning growth and blood parameters of milk replacer fed and naturally suckled Black Bengal kids
}

\author{
M Moniruzzaman**, S Afroz*, A Khatun, MH Alam, MN Islam and MR Amin \\ Department of Animal Science, Bangladesh Agricultural University, Mymensingh- 2202, Bangladesh
}

\begin{abstract}
The present study was carried out to know the effect of feeding soybean-based milk replacer on postweaning growth and blood parameters of milk replacer-fed and naturally suckled goat kids. Twenty four Black Bengal kids were allocated into two groups; treatment group ( $n=12,6$ male and 6 female) was reared artificially with milk replacer, and control group $(n=12,6$ male and 6 female) was kept with their dam for natural suckling. Milk replacer was prepared with powdered milk and soybean powder (1:1). After weaning, the live weight of kids was recorded weekly. The blood samples were collected from the kids to determine haematological parameters. The live weight did not differ significantly between artificially fed and naturally suckled male and female kids. Wither height and heart girth showed significantly $(p<0.05)$ higher in the milk replacer fed male kids than naturally reared males. Body length of female kids was significantly $(p<0.05)$ higher in milk replacer fed group than naturally suckled group. Heart girth and red blood cell $(R B C)$ were found significantly $(p<0.05)$ higher in artificially fed kids than naturally reared both male and female kids. Therefore, it can be concluded that artificial feeding with milk replacer can be an alternative way of kid rearing under farm conditions.
\end{abstract}

Keywords: Soymilk, milk replacer, kids, growth and haematological parameters.

\section{Introduction}

Black Bengal goats are meat type goats usually found all over Bangladesh and its surrounding areas in India. They are popular for their adaptability in a hot and humid environment, high prolificacy and delicious meat (Hossain, 2021). Black Bengal goats are also well known for their skin quality which is commercially called "Kustia Grade". They have the potential for better fertility and litter size. A high level of kid mortality is a significant barrier to increasing goat production in tropical and subtropical countries. The main factors are closely related to higher kid mortality, lower birth weights, and lower milk production by the dam. In this regard, artificial (bottle) feeding of the newborn is essential. Artificial rearing of goat kids with whole milk is expensive due to the high cost and demand for cow milk for human consumption. So artificial rearing of kids with milk replacers has been considered as an economic and alternate way to save the kids.
The success in artificial feeding with milk replacer depends on many factors like breed, milk quality, access to feed and pasture environment, and system of milk feeding. The first milk replacer was formulated by Kellner (1926). Several studies of milk replacer on different species (Kids, Lambs, Calves) found higher average daily weight gain with the development and establishment of rumen microorganisms and reduced mortality (Emsen et al., 2004; Hu et al., 2020; Zhang et al., 2019). It is known that milk replacer is cheaper than natural milk (Khan et al., 2012). Milk replacers are usually made with skim milk powder, animal fat, buttermilk powder, whey protein, soy lecithin, and vitamin-mineral premix. Glucose, cereal flower, non-milk protein can also be used in little amounts. Milk replacers are prepared with several ingredients to supply protein, fat, lactose, minerals, and vitamins and dissolved readily in water to facilitate feeding in a physical form similar to milk. Milk is an essential feed for newborn kids for 3-4 weeks or up to 5-6

\#These authors contributed equally.*Corresponding author: monir.as@bau.edu.bd 
months depending on breed and other factors (Sultana et al., 2012). It is difficult to find out an acceptable alternative to milk protein.

Soybean is a source of high-quality, relatively inexpensive protein that has the potential for using in milk replacer (Ghorbani et al., 2007). Partially replacement of whole milk with soymilk on pre-weaning calf performance and weaning costs results from soymilk as an economic partial substitute for whole milk in calf-raising (Ghorbani et al., 2007). Soy flour can supply the one-third of the total protein in milk replacer as a single contributor without compromising growth performance (Heaney and Shrestha, 1987). They also reported that there were no significant differences in daily gains from birth to weaning and post-weaning feed conversions among lambs fed standard milk replacer with all the protein provided by milk products and those fed milk replacer containing soy protein. Sarker et al. (2015) suggested that soybean-based milk replacer could be supplied to kids up to $50 \%$ without any detrimental effects on their growth and organ development. However, the effect of that artificial feeding of soybean-based milk replacer was not compared with the naturally reared kids. Therefore, this study was conducted to know the post-weaning growth and blood parameters of milk replacer fed and naturally suckled kids.

\section{Materials and methods}

\section{Kids and their management}

The experiment was conducted at Charsottrapur, Boira, and Kewatkhali in Mymensingh Sadar Upazilla, Mymensingh, Bangladesh. Two weeks old 24 Black Bengal kids were divided into two groups considering their initial weight, litter size of their dam, parity, and dam weight. Each group consisted of 12 kids ( 6 male, 6 female). The house was well ventilated and cleaned properly. All feeders, waterers and other necessary equipments were also cleaned and disinfected regularly. Freshly dried bedding material was spread on the floor. The gunny bag was hung over the ventilator to protect rain and wind. The initial weights of kids ranged from 1.16 to $1.65 \mathrm{~kg}$ and they were identified with tags. The kids were reared in separate rooms for natural (suckling with mother) and artificial groups (50\% powder milk $+50 \%$ soymilk).

Milk replacer was supplied individually using a bottle with a soft rubber nipple. Milk replacer was offered @ $10 \%$ of the live weight of kids. The amount of milk replacer supplied to the kids was gradually reduced to zero by the end of week 13 , using week 7 as base intake @2\% level. In addition to milk replacer, all the kids were offered concentrate mixture ( $24 \%$ crude protein) and green grasses ad libitum basis. After five weeks, the concentrates supplementation to the kids was increased gradually up to the end of the experiment. Kids were provided free access to water.

\section{Preparation of soymilk}

An amount of $62.5 \mathrm{~g}$ soy flour dissolved in 1000 $\mathrm{ml}$ water and boiled at $100^{\circ} \mathrm{C}$ for 10 minutes with constant stirring. After stirring and prompt cooling, an equal amount (1:1) of powder milk was mixed and then supplied to the kids.

\section{Live weight}

Each kid was weighed weekly at early in the morning using a digital balance. The kids were kept off feed overnight (16 hours) before weighing.

\section{Collection and processing of blood}

Blood samples were collected at the $7^{\text {th }}$ week of the experimental period via jugular vein puncture into evacuated tubes containing EDTA (Ethylenediaminotetraacetate) for examination of RBC, white blood cell (WBC), haemoglobin ( $\mathrm{Hb}$ ), erythrocyte sedimentation rate (ESR) and packed cell volume (PCV).

\section{Statistical analysis}

Data were presented as the mean \pm SD (standard deviation). All data were subjected to one-way ANOVA, and the significance of difference among means was determined using Tukey's HSD test. All analyses were conducted in "SAS/STAT version 9.1.3" for Windows Service Pack 4, 2004 SAS Institute, and Cary NC USA for Windows. Differences at $\mathrm{p}<0.05$ were considered statistically significant. 


\section{Results and discussion}

In the present study, Black Bengal goat kids were reared artificially with soybean-based milk replacers while another group was reared naturally keeping with their mother to see the post-weaning growth and blood parameters. The results showed that the post-weaning growth of kids did not differ significantly between milk replacer fed and naturally fed kids (Figure 1 and
2). All the kids of both the groups showed a positive increasing trend in live weight change with the progress of time. The final live weight did not differ significantly between male and female groups (Table 1). Lama et al. (2013) studied the growth of Criollo kids in three rearing systems i.e., naturally reared with their mothers, suckling goat milk until 30 and 45 days of age at weaning, and artificially reared on milk replacer until 45 days of age).

Table 1: Live weight gain and body measurements of milk replacer fed and naturally suckled Black Bengal kids at post-weaning stage.

\begin{tabular}{|c|c|c|c|c|c|}
\hline \multirow{2}{*}{\multicolumn{2}{|c|}{ Parameters }} & \multicolumn{2}{|c|}{ Male } & \multicolumn{2}{|c|}{ Female } \\
\hline & & $\begin{array}{c}\text { Artificial } \\
\text { feeding }\end{array}$ & $\begin{array}{l}\text { Natural } \\
\text { suckling }\end{array}$ & $\begin{array}{c}\text { Artificial } \\
\text { feeding }\end{array}$ & $\begin{array}{c}\text { Natural } \\
\text { suckling }\end{array}$ \\
\hline \multicolumn{2}{|c|}{ Initial live weight (kg) } & $5.69 \pm 0.35$ & $5.26 \pm 0.61$ & $5.63 \pm 0.67$ & $5.52 \pm 0.73$ \\
\hline \multicolumn{2}{|c|}{ Final live weight $(\mathrm{kg})$} & $13.55 \pm 0.75$ & $12.6 \pm 0.85$ & $12.00 \pm 0.87$ & $11.21 \pm 0.62$ \\
\hline \multicolumn{2}{|c|}{ Total weight gain (kg) } & $7.86 \pm 0.72$ & $7.34 \pm 0.27$ & $6.27 \pm 0.20$ & $5.69 \pm 0.69$ \\
\hline \multicolumn{2}{|c|}{ Body length (cm) } & $51.0 \pm 1.22$ & $50.0 \pm 1.41$ & $51.66^{a} \pm 0.87$ & $48.03^{b} \pm 0.33$ \\
\hline \multicolumn{2}{|c|}{ Wither height (cm) } & $43.0^{\mathrm{a}} \pm 0.70$ & $41.73^{b} \pm 0.40$ & $42.0 \pm 0.70$ & $41.67 \pm 0.52$ \\
\hline \multicolumn{2}{|c|}{ Heart girth $(\mathrm{cm})$} & $48.0^{\mathrm{a}} \pm 0.89$ & $46.50^{\mathrm{b}} \pm 0.81$ & $46.33^{a} \pm 0.60$ & $44.41^{b} \pm 0.73$ \\
\hline \multirow{3}{*}{$\begin{array}{l}\text { Circumference } \\
\text { of neck }(\mathrm{cm})\end{array}$} & Apex & $21.5 \pm 0.77$ & $21.08 \pm 0.80$ & $19.08 \pm 0.80$ & $21.25 \pm 0.68$ \\
\hline & Middle & $23.08 \pm 0.37$ & $22.33 \pm 0.75$ & $20.75 \pm 1.72$ & $21.80 \pm 0.70$ \\
\hline & Base & $22.07 \pm 0.49$ & $22.75 \pm 1.08$ & $23.16 \pm 0.63$ & $22.75 \pm 1.72$ \\
\hline \multicolumn{2}{|c|}{ Neck length (cm) } & $13.73 \pm 0.43$ & $12.75 \pm 1.08$ & $12.36 \pm 0.67$ & $11.33 \pm 0.68$ \\
\hline
\end{tabular}

*Data were presented as (mean $\pm S D) ;{ }^{a-b}$ Within a row, means with different superscripts are significantly different $(p<0.05)$.

They reported that the growth of kids did not differ significantly between the rearing systems. These results are consistent with the findings of present study. Delgado-Pertinez et al. (2009) examined the differences between natural or artificial, where they found that kid growth did not significantly differ at the $4^{\text {th }}$ week of age, although the natural suckled kids weighed slightly more than those of the milk replacer fed kids. In contrast, Arguello et al. (2004) reported a higher average daily gain of natural suckled kids than adlibitum and restricted milk replacer fed kids. Baumrucker and Blum (1993) also reported that dams' milk contains a growth promoter that is absent in milk replacers, which supports the higher average daily gain in natural suckled kids. In this current study, wither height and heart girth were significantly $(p<0.05)$ higher in the milk replacer fed group than naturally reared male kids (Table 1). In female kids, body length and heart girth were significantly $(p<0.05)$ higher in milk replacer fed kids than naturally reared female kids. In case of male, body length and in case of both male and female groups, circumference of neck and neck length did not differ significantly between milk replacer fed and naturally fed kids. Kaiwu et al. (2015) reported that there was no significant difference in withers height, body length, and heart girth between milk replacer and control group. Also, Perez et al. (2001) did not find any significant differences in body length when kids fed either goat milk only or commercial calf milk substitute/ replacer or a goat kid milk substitute/replacer. 


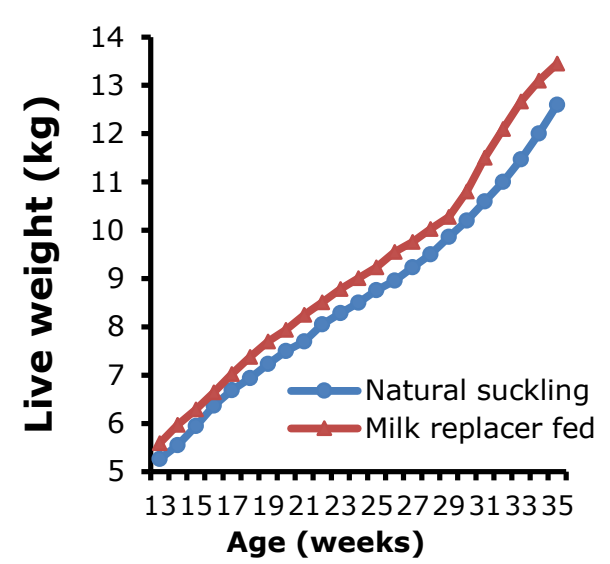

Figure 1: Post-weaning growth of male kids

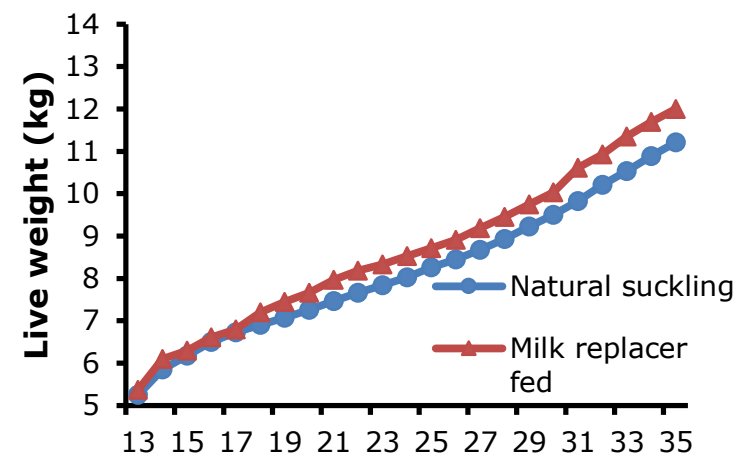

Age (weeks)

Figure 2: Post-weaning growth of female kids

Table 2: Blood parameters of milk replacer fed and naturally suckled Black Bengal kids at post-weaning stage.

\begin{tabular}{|c|c|c|c|c|c|}
\hline \multirow{2}{*}{\multicolumn{2}{|c|}{ Blood parameters }} & \multicolumn{2}{|c|}{ Male } & \multicolumn{2}{|c|}{ Female } \\
\hline & & $\begin{array}{l}\text { Artificial } \\
\text { Feeding }\end{array}$ & $\begin{array}{l}\text { Natural } \\
\text { Suckling }\end{array}$ & $\begin{array}{l}\text { Artificial } \\
\text { Feeding }\end{array}$ & $\begin{array}{l}\text { Natural } \\
\text { Suckling }\end{array}$ \\
\hline \multicolumn{2}{|c|}{ Red Blood Cell (millions $/ \mathrm{mm}^{3}$ ) } & $8.5^{\mathrm{a}} \pm 0.14$ & $7.60^{b} \pm 0.35$ & $7.69^{\mathrm{a}} \pm 0.51$ & $6.55^{b} \pm 0.26$ \\
\hline \multicolumn{2}{|c|}{ White Blood Cell (thousands $/ \mathrm{mm}^{3}$ ) } & $7.95 \pm 0.23$ & $7.3 \pm 0.48$ & $8.02 \pm 0.23$ & $6.37 \pm 0.27$ \\
\hline \multicolumn{2}{|c|}{ Hemoglobin ( $\mathrm{g}$ ) } & $6.95 \pm 0.34$ & $7.25 \pm 0.05$ & $7.41 \pm 0.40$ & $6.63 \pm 0.61$ \\
\hline \multicolumn{2}{|c|}{ Packed Cell Volume (\%) } & $26.0 \pm 1.0$ & $24.0 \pm 2.65$ & $24.0 \pm 3.61$ & $19.67 \pm 2.08$ \\
\hline \multirow{5}{*}{ 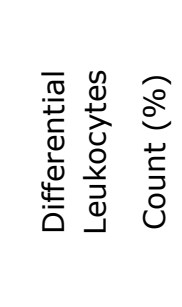 } & Neutrofil (\%) & $31.0 \pm 1.73$ & $30.67 \pm 2.89$ & $33.33 \pm 2.08$ & $32.67 \pm 2.08$ \\
\hline & Eosinophil (\%) & $3.33 \pm 0.58$ & $3.0 \pm 1.00$ & $2.00 \pm 1.0$ & $3.33 \pm 0.58$ \\
\hline & Lymphocyte (\%) & $63.76 \pm 2.52$ & $64.33 \pm 4.04$ & $61.67 \pm 1.53$ & $62.33 \pm 1.53$ \\
\hline & Monocyte (\%) & $2.78 \pm 0.68$ & $2.63 \pm 0.72$ & $3.00 \pm 1.0$ & $2.67 \pm 0.58$ \\
\hline & Basophil (\%) & 0 & 0 & 0 & 0 \\
\hline
\end{tabular}

*Data were presented as (mean $\pm S D$ ); ${ }^{a-b}$ within a row, means with different superscripts are significantly different $(p<0.05)$.

Masum et al. (2011) reported that body length, wither height, and heart girth did not differ significantly between the milk replacer fed and whole milk fed calves. However, it was not clearly understood why the body frame was larger in milk replacer fed kids than the control groups in the present study.

The numbers of RBC of male and female kids were significantly higher $(p<0.05)$ in milk replacer fed kids than naturally suckled kids (Table 2). Addas et al. (2010) reported that males had higher RBC values than females. In the young ruminants, the high RBC values may be due to excitement or strenuous exercise during handling (Gartner et al., 1969). The secretion of adrenaline leads to spleen contracts and thus results from the release of more $\mathrm{RBC}$ into circulation. The values of $\mathrm{WBC}, \mathrm{Hb}$, and PCV percentage were almost similar in both natural and milk replacer fed kids.

\section{Conclusions}

Soybean-based milk replacer can be fed as an alternative to goat milk without having any significantly negative effect on growth and blood 
parameters at post-weaning stage of Black Bengal kids.

Acknowledgments: This research was funded by the Bangladesh Agricultural University Research System (BAURES).

Conflict of interest: The authors declare that there is no conflict of interest that could be perceived as prejudicing the impartiality of the research reported and any financial organization regarding the material discussed in the manuscript.

\section{References}

Addas PA, Midau A, Babale DM (2010). Heamatobiochemical findings of indigenous goats in Mubi Adamawa State Nigeria. Journal of Agricultural and Social Science, 6: 14-16.

Arguello A, Castro N, Capote J (2004). Growth of Milk Replacer kids fed under three different managements. Journal of Applied Animal Research, 25: 37-40.

Baumrucker CR, Blum JR (1993). Secretion of insulin-like growth factors in milk and their effect on neonate. Livestock Production Science, 35: 49-72.

Delgado-Pertíñez $\quad \mathrm{M}$ ， Guzmán-Guerrero JL, Caravaca FP, Castel JM, Ruiz FA, GonzálezRedondo P, Alcalde MJ (2009). Effect of artificial vs. natural rearing on milk yield, kid growth and cost in Payoya autochthonous dairy goats. Small Ruminant Research, 84: 108-115.

Dukes HH (1955). The physiology of domestic animals. 7th Edn. Baillers Tindall and Co. London. P. 96-98.

Emsen E, Yaprak M, Bilgin O, Ockermanb H (2004). Growth performance of Awassi lambs fed calf milk replacer. Small Ruminant Research, 53: 99-102.

Gartner RJW, Callow LL, Granzien CK (1969). Variation in the concentration of blood constituents in relation to handling of cattle. Research in Veterinary Science, 10: 7-12.

Ghorbani GR, Kowsar R, Alikhani M, Nikkhah A (2007). Soymilk as a novel milk replacer to stimulate early calf starter intake and reduce weaning age and costs. Journal of Dairy Science, 90: 5692-5697.

Hu W, Hill TM, Dennis TS, Suarez-Mena FX, Aragona KM, Quigley JD, Schlotterbeck RL (2020). Effects of milk replacer feeding rates on growth performance of Holstein dairy calves to 4 months of age, evaluated via a meta-analytical approach. Journal of dairy science, 103: 2217-2232.

Heany DP, Shrestha JNB (1987). Effects of soy flour in milk replacer on the performance of artificially reared lambs. Canadian Journal of Animal Science, 67: 757-763.

Hossain ME (2021). Performance of Black Bengal goat: a 50-year review. Tropical Animal Health and Production, 53: 1-15.

Kaiwu H, Yan T, Bingwen S, Guishan X, Jiangpeng G, Feng G, Chuntao Y, Qiyu D (2015). Effects of protein sources for milk replacers on growth performance and serum biochemical indexes of suckling calves. Animal Nutrition, 1: 349355.

Kellner O (1926). The scientific feeding of animals (Trans. by Goodwin, W.). London: Duckworth \& Co., Ltd, 314.

Khan R, Ghufranullah AS, Khan BD, Iqbal M, Pervez FK (2012). Effect of milk replacer on performance parameters of different bovine breeds. Pakistan Journal of Nutrition, 11:11901193.

Lama SP, Egeaa V, Grilli D, Fucili M, Allegretti L, Guevaraa JC (2013). Growth and economic performance of kid production under different rearing systems and slaughter ages in arid areas of Argentina. Small Ruminant Research, 110: 9-14.

Masum AKM, Islam MN, Khan MAS, Rahman SME, Myoung-Su P, Fereidoun F, Wang J, Joong-Hyun P, Deong-Hyun O (2011). Partial replacement of whole milk with vitamin-mineral fortified soymilk for rearing calves. Journal of Agricultural Science, 27: 225-229.

Perez P, Maino M, Morales MS, Soto A (2001). Effect of goat milk and milk substitutes and sex on productive parameters and carcass composition 
of Creole kids. Small Ruminant Research, 42: 87-94.

Sarker MB, Alam MH, Saha BK, Amin MR, Moniruzzaman M (2015). Effects of soybean milk replacer on growth, meat quality, rumen and gonad development of goats. Small Ruminant Research, 130: 127-135.

Silva AG, Huber JT, Herdt TH, Hollan R, Degregorio RM, Mullaney TP (1986). Influence of substituting two types of soybean protein for milk protein on gain and utilization of milk replacers in calves. Journal of Dairy Science, 69: $172-180$.
Sultana S, Khan MJ, Hassan MR, Khondoker MAMY (2012). Effects of concentrate supplementation on growth, reproduction and milk yield of Black Bengal goats (Capra hircus). Bangladesh Veterinarian, 29: 7-16.

Vacca GM, Pazzola M, Piras G, Pira E, Paschino P, Dettori ML (2014). The effect of cold acidified milk replacer on productive performance of suckling kids reared in an extensive farming system. Small Ruminant Research, 121: 161167.

Zhang R, Zhang WB, Bi YL, Tu Y, Beckers Y, Du HC, Diao QY (2019). Early feeding regime of waste milk, milk, and milk replacer for calves has different effects on rumen fermentation and the bacterial community. Animals, 9: 443. 